\title{
The role of varietal attributes on adoption of improved seed varieties: the case of sorghum in Kenya
}

\author{
Anne Gesare Timu*, Richard Mulwa ${ }^{2}$, Julius Okello ${ }^{2}$ and Mercy Kamau ${ }^{3}$
}

\begin{abstract}
This paper examined the effect of variety attributes on adoption of improved sorghum varieties in Kenya. Using data from a random sample of 140 farmers, a multivariate probit was used to identify variety-specific drivers of adoption. The results on the perception of farmers variety attributes showed that improved varieties had desirable production and marketing attributes while the local varieties were perceived to have the best consumption attributes. Evidence further indicated that the major sorghum variety attributes driving rapid adoption are taste, drought tolerance, yield, ease of cooking, and the variety's ability to fetch a price premium. Early maturity, a major focus of research was found to have no effect on the adoption decision. The findings of the study implied that, while developing improved seed varieties, breeders should also focus on non-yield attributes like taste and ease of cooking to increase adoption and satisfy the multiple needs of the farmers.
\end{abstract}

Keywords: Sorghum, Variety attributes, Multi variateprobit model, Adoption

\section{Background}

Sorghum (Sorghum Bicolor L. Moench) is one of the main staple crops for the world's poorest and food-insecure people. It is the second major crop (after maize) across all ecologies in Africa and is one of the main staples for people in Eastern and Southern Africa (ESA). Sorghum is a dual-purpose crop where both grain and stover are highly valued outputs. Globally, sorghum is grown in 46 million hectares accounting for an annual production of 60 million tones [1]. Developing countries account for $90 \%$ of total area and $70 \%$ of total output, with Africa and Asia each accounting for $20 \%$ to $30 \%$ of the global production. In Africa sorghum is mainly cultivated by small-scale resource poor farmers and production is characterized by limited use of fertilizer and improved seeds [2]. In Kenya, sorghum is an important traditional food crop in the dry land areas of Nyanza, Eastern, and Coast provinces. On average, the crop occupies an area of 139,000 hectares with an annual production of 110,000 tons [3]. The country's per-capita sorghum consumption is approximately $3.0 \mathrm{~kg}$ per year.

\footnotetext{
* Correspondence: annegesare@yahoo.com

'International Livestock Research Institute, Nairobi, Kenya

Full list of author information is available at the end of the article
}

Despite the numerous benefits of sorghum, its production in Kenya has remained heavily constrained by diseases, insect pest damages, and rainfall variability. In response to these constraints, national and international research organizations have developed and released several highyielding and stress tolerant varieties of sorghum with desirable agronomic and market traits. The development of improved sorghum varieties in Kenya started in the early 1970s and by the year 2005, at least seven varieties had been released in the country [4]. They include; Gadam, Serena, Seredo, KARI Mtama 1, KARI Mtama 3, IS76\#23, and KAK 7780. The release of the varieties was followed by an intensive promotion programme by the Ministry of Agriculture under the orphan crop multiplication programme and the Eastern province horticulture and traditional food crops project. Reports indicate that the adoption of the sorghum varieties has been good both in the medium and marginal low potential areas of the province [5].

Although technology adoption remains one of the most researched areas in agricultural economics, very few studies [6-9] have looked at the adoption of improved sorghum varieties. Further, the existing studies have focused on the role of socioeconomic, institutional, and policy factors 
in explaining the adoption of improved sorghum varieties. This paper distinguishes itself by providing a greater insight into sorghum studies by focusing on the effect of variety attributes on adoption.

Another motivation for this study is that, many previous adoption studies have only focused on one improved variety (for example, [10-12] by using the conventional logit or probit approach. However, in the present study, more than one improved varieties exist each with varying production, consumption, and marketing traits and farmers are more likely to simultaneously adopt more than one variety in order to address their multiple needs. We use a multivariate probit regression which allows estimation of several correlation binary choices jointly [13]. The multi variateprobit model takes into account the potential interdependence in technology choice and the possible correlation in the adoption of alternative improved varieties. The probability of adoption of any particular sorghum variety is estimated conditional on the choice of any other related variety.

This paper is based on data collected from a stratified random sample of 140 sorghum farmers in Mbeere South County of Kenya. Mbeere South County is in an ASAL area of Kenya and sorghum is mainly grown as a food crop to edge farmers against the risk of crop failure. The rest of the paper is organized as follows:section two presents the methods and the variables used in the empirical analysis while section three reports and discusses the results; section four concludes.

\section{Empirical model}

A multivariate probit was used to analyze the effect of varietal characteristics on adoption of improved sorghum varieties. A multivariate probit has been used previously in a number of adoption studies [14-16], the model accounts for simultaneous adoption of multiple varieties and the potential correlations among the adoption decisions. The multivariate probit is an extension of the probit model [13] and is used to estimate several correlated binary outcomes jointly.

The model is specified as follows:

$$
Y_{i m}^{*}=\beta_{m} X_{i m}+\varepsilon_{i m}
$$

Where $Y_{i m}^{*}(m=1, \ldots, k)$ represent the unobserved latent variable of improved sorghum varieties adopted by the $i^{\text {th }}$ farmer. $(i=1, \ldots, n)$. Out of the seven improved varieties released to farmers in the study area, only two varieties were widely adopted (Gadam and Serena), very few farmers had adopted Seredo and KARI Mtama 1 while no farmer had adopted KARI Mtama3, IS76\#23, and KAK 7780. Therefore, the analysis was limited to only two improved varieties; Kimbeere variety (the most common local variety) was also included in the analysis for comparison purposes.
Therefore, in this case $\mathrm{k}=$ Serena,Gadam, and Kimbeere. $X_{i m}$ is a $1 \times k$ vector of observed variables that affect the variety adoption decision, the variables include household socioeconomic, institutional factors, and variety attributes. $\beta_{m}$ is a $k \times 1$ vector of unknown parameters to be estimated $\varepsilon_{i m}, m=1, \ldots, M$ are the error terms distributed as multivariate normal, each with a mean of zero, and variance-covariance matrix $\mathrm{V}$, where $\mathrm{V}$ has values of 1 on the leading diagonal and correlations [17].

Equation (1) is a system of $m$ equations that as shown in Equation 2 below;

$$
\left\{\begin{array}{l}
Y_{1}^{*}=X_{1} \beta_{1}+\varepsilon_{1} Y_{1}=1 \text { if } Y_{1}^{*} \succ 0, Y_{1}=0 \text { otherwise } \\
Y_{2}^{*}=X_{2} \beta_{2}+\varepsilon_{2} Y_{2}=1 \text { if } Y_{2}^{*} \succ 0, Y_{2}=0 \text { otherwise } \\
Y_{3}^{*}=X_{3} \beta_{3}+\varepsilon_{3} Y_{3}=1 \text { if } Y_{3}^{*} \succ 0, Y_{3}=0 \text { otherwise }
\end{array}\right\}
$$

This system of equations is jointly estimated using maximum likelihood method.

The implicit functional form of the empirical model is specified as follows: decision to adopt $=f$ (age, gender, education, farming experience, household size, farm size, off-farm income, distance to the market, extension visits, non-livestock asset value, group membership, yield, drought tolerance, pest resistance, maturity, farm gate price, cooking qualities, striga resistance, brewing qualities, and taste) $+\varepsilon$.

\section{Results and discussion}

A simple descriptive analysis was conducted to identify the socioeconomic conditions of the farm households (Table 1). The results showed that about $84 \%$ of the sampled households were male headed while the average year of formal education for the entire population was 7 years. The average household size of the total population was five persons which corresponds with the Kenya's national mean figure of five members per household [18]. The mean age of adopters was 49 years while for non-adopters it was 56 years. The mean farm size of adopters was 5.9 acres compared to 3.9 acres for nonadopters. The mean value of all livestock assets was Kshs 43,000 and Kshs 41,000 for adopters and nonadopters, respectively. On the other hand, the approximate value of non-livestock assets was Kshs 96,000 and Kshs 86,000 for adopters and non-adopters, respectively to the nearest extension agent was used as a proxy for information access. The average distance to the nearest extension agent was $4 \mathrm{~km}$ and $5.5 \mathrm{~km}$ for the adopters and non-adopters, respectively.

Distances to the nearest market and nearest all weather roads were used as proxies for market access. On average, adopters had better access to market $(5.3 \mathrm{~km})$ than nonadopters $(6.7 \mathrm{~km})$. Similarly, the distance to the nearest extension agent was used as a proxy for information 
Table 1 Means of socioeconomic variables of the surveyed households

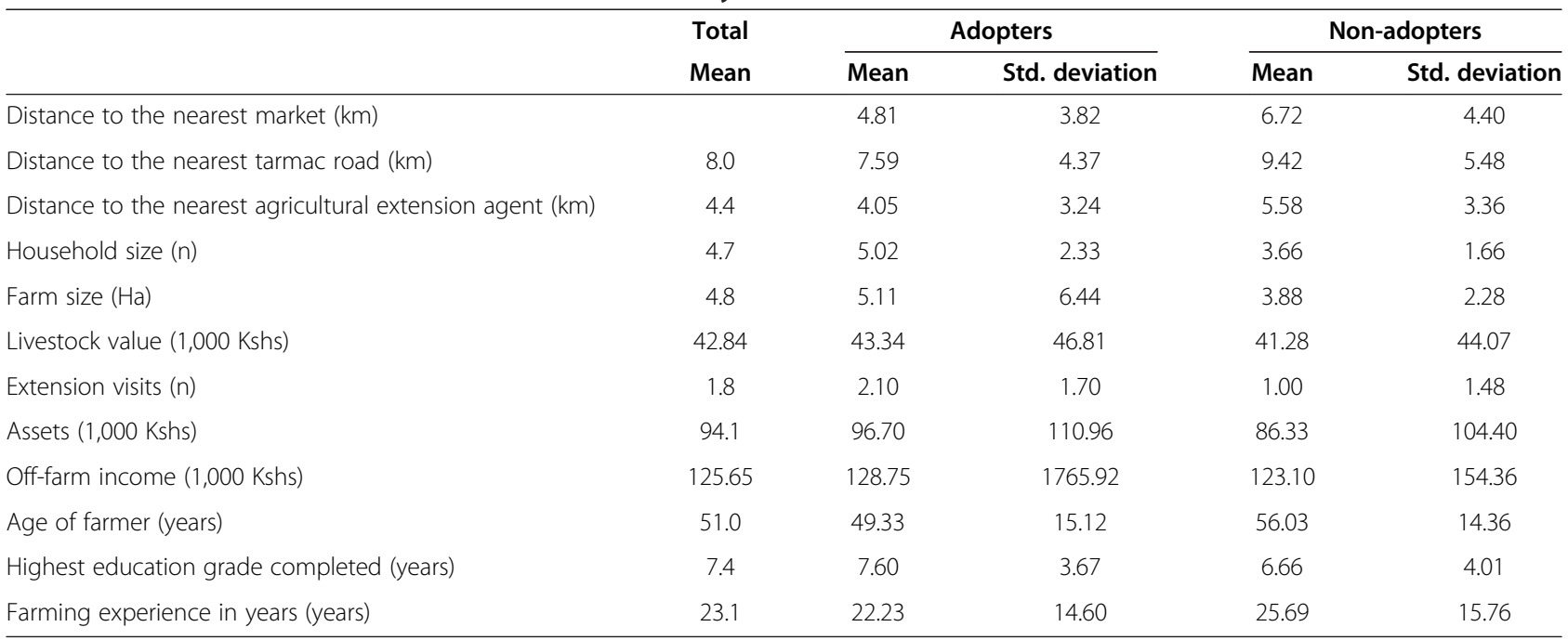

access. The average distance to the nearest extension agent was $4 \mathrm{~km}$ and $5.5 \mathrm{~km}$ for the adopters and nonadopters, respectively.

\section{Adoption of improved sorghum varieties}

Table 2 presents the results from analysis of farmers' awareness and adoption of different varieties. The results showed that both local and improved sorghum varieties are grown in the study area. The improved varieties grown include Gadam, Serena, Seredo, and KARI Mtama 1, while the local varieties include Kimbeere, Gatururu, and Muceru. Among the improved varieties, Gadam and Serena are the most widely known varieties followed by Seredo. About $85 \%$ and $90 \%$ of the households indicated that they know Serena and Gadam, respectively. About $57 \%$ and $44 \%$ of the respondents have planted Serena and Gadam varieties before although only $53 \%$ and $32 \%$ of the households planted the respective varieties during the 2010 long rain planting season. This

Table 2 Sorghum variety knowledge and adoption

\begin{tabular}{lccc}
\hline Variety & $\begin{array}{c}\text { Households } \\
\text { knowing the } \\
\text { variety (\%) }\end{array}$ & $\begin{array}{c}\text { Ever grown } \\
\text { the variety (\%) }\end{array}$ & $\begin{array}{c}\text { Grew the variety } \\
\text { last season (\%) }\end{array}$ \\
\hline Serena & 85 & 57 & 53 \\
Seredo & 8 & 7 & 5 \\
KARI Mtama 1 & 3 & 2 & 1 \\
KARI Mtama 3 & 0 & 0 & 0 \\
Gadam & 90 & 44 & 32 \\
IS76\#23 & 0 & 0 & 0 \\
Kimbeere & 98 & 98 & 31 \\
Gatururu & 78 & 40 & 8 \\
Muceru & 89 & 36 & 8 \\
\hline
\end{tabular}

could be attributed to seed scarcity and unfavorable environmental conditions. The KARI Mtama 3 and IS76\#23 varieties were not common among the surveyed households and no household indicated to have planted the varieties before. The most widely known traditional variety is the Kimbeere variety. About 98\% of the surveyed households have planted the Kimbeere variety at least once and approximately $31 \%$ planted it during the 2010 season. About $24 \%$ of the households exclusively planted traditional varieties which indicate that adoption of improved varieties is relatively high.

\section{Farmers' perception of improved sorghum varieties attributes}

Farmers were asked to score the desirable attributes of the different varieties on a scale of $1=$ poor, $2=$ average and 3 =good. Table 3 shows the average scores with regard to different agronomic, consumption, and marketing attributes as scored by farmers. Regarding

Table 3 The average scores of farmers perceptions of sorghum variety attributes

\begin{tabular}{lccc}
\hline & \multicolumn{3}{c}{ Variety } \\
\cline { 2 - 4 } Variety attribute & Serena & Gadam & Kimbeere \\
\hline Grain yield & 2.60 & 2.53 & 1.97 \\
Drought tolerance & 2.10 & 2.29 & 2.42 \\
Striga resistance & 2.18 & 2.27 & 2.35 \\
Pest resistance & 1.79 & 2.31 & 2.10 \\
Early maturity & 2.72 & 2.61 & 1.60 \\
Price(Ksh/kg) & 2.21 & 2.49 & 1.90 \\
Cooking time & 2.49 & 2.24 & 2.29 \\
Taste & 2.44 & 1.99 & 2.53 \\
Brewing quality & 2.19 & 2.27 & 2.50 \\
\hline
\end{tabular}


the yield of the various sorghum varieties, the two improved varieties had good grain yield potential as compared to the local variety; Serena variety had the best yields with an average score of 2.6 while Kimbeere variety had a score of 1.9 . With regard to drought tolerance and striga resistance, both local and improved varieties scored highly (with mean score value of above 2). However, contrary to our expectations, the local Kimbeere variety was scored highly with regard to drought tolerance.

Variety maturity rate is an important production attribute. Among the three varieties considered, Serena variety had the highest maturity score (2.72) whereas the Kimbeere variety was scored the least (1.6). Gadam variety had the best prices; however, Kimbeere variety was scored highly with regard to consumption attributes like taste. Overall, the improved varieties were scored highly with regard to marketing attributes and partly, they had good production attributes for instance grain yield. On the other hand, the local variety had desirable consumption attributes like taste and production attribute like drought tolerance.

\section{Drivers of variety adoption}

The multi variateprobit system was estimated jointly for three dependent variables: Gadam, Serena, and Kimbeere. The results of the analysis are presented in Table 4 below. The Pvalue of the Wald test statistics for the overall significance of the regression is very low (0.0001) indicating that the multi variate regression is highly significant. Further, the likelihood ratio test of rho is highly significant $(P$ value $=0.000)$ indicating that a multivariate probit specification fits the data.

Another important result is that the correlation coefficients among the error terms are significant indicating that the decision to adopt one variety affects the decision to adopt the other (Table 3). The correlation coefficient between the two improved sorghum varieties is positive and significant at $1 \%$. On the other hand, the correlation coefficients between the local Kimbeere variety and the two improved variety are both negative and significant at the $5 \%$ level. These results point to the cross-equation correlation of the error terms and hence interdependence in the adoption of improved varieties. This also indicates that farmers who adopt one improved sorghum variety

Table 4 Factors affecting adoption of improved sorghum varieties: results of multivariate probit regression

\begin{tabular}{|c|c|c|c|c|c|c|c|c|c|}
\hline & \multicolumn{3}{|c|}{ Gadam } & \multicolumn{3}{|c|}{ Serena } & \multicolumn{3}{|c|}{ Kimbeere } \\
\hline & Coefficient & Pvalue & Marginal effect & Coefficient & Pvalue & Marginal effect & Coefficient & Pvalue & $\overline{\text { Marginal effect }}$ \\
\hline Yield & 0.559 & 0.021 & 0.462 & 0.239 & 0.021 & 0.335 & -1.109 & 0.028 & -0.261 \\
\hline Drought resistance & 0.580 & 0.247 & 0.146 & 0.980 & 0.698 & 0.201 & 0.967 & 0.040 & 0.310 \\
\hline Striga & 0.093 & 0.247 & 0.022 & 0.573 & 0.459 & 0.230 & -0.283 & 0.534 & -0.106 \\
\hline Maturity & -0.705 & 0.103 & -0.203 & 0.744 & 0.413 & 0.242 & 0.499 & 0.199 & 0.192 \\
\hline Pest resistance & 1.067 & 0.084 & 0.674 & 1.757 & 0.001 & 0.564 & 0.903 & 0.072 & 0.330 \\
\hline Price & 2.371 & 0.000 & 0.118 & 1.065 & 0.154 & 0.354 & 0.116 & 0.801 & 0.027 \\
\hline Ease of cooking & 1.182 & 0.019 & 0.329 & 0.755 & 0.017 & 0.332 & -0.810 & 0.097 & -0.293 \\
\hline Taste & 0.372 & 0.433 & 0.118 & -0.330 & 0.645 & -0.145 & 0.801 & 0.059 & 0.283 \\
\hline Brewing quality & 0.259 & 0.048 & 0.065 & 1.201 & 0.124 & 0.354 & 0.204 & 0.520 & 0.052 \\
\hline Distance to the market & -0.159 & 0.001 & -0.052 & -0.012 & 0.832 & -0.005 & 0.051 & 0.448 & 0.011 \\
\hline Household size & 0.121 & 0.096 & 0.039 & 0.132 & 0.223 & 0.050 & -0.136 & 0.001 & -0.420 \\
\hline Farm size & 0.620 & 0.019 & 0.189 & 0.183 & 0.616 & 0.041 & -0.047 & 0.849 & -0.030 \\
\hline Value of livestock assets & 0.177 & 0.138 & 0.055 & -0.275 & 0.126 & -0.105 & 0.070 & 0.551 & 0.025 \\
\hline Extension visits & 0.335 & 0.003 & 0.113 & 0.085 & 0.053 & 0.223 & -0.084 & 0.038 & -0.260 \\
\hline Off-farm income & 0.664 & 0.006 & 0.223 & 0.319 & 0.028 & 0.127 & 0.285 & 0.146 & 0.106 \\
\hline Group membership & -0.440 & 0.194 & -0.151 & -0.049 & 0.906 & -0.018 & -0.389 & 0.021 & -0.136 \\
\hline Assets & 0.047 & 0.076 & 0.330 & 0.284 & 0.151 & 0.598 & 0.008 & 0.954 & 0.008 \\
\hline Age & -1.748 & 0.020 & -0.484 & -1.056 & 0.285 & -0.331 & 0.618 & 0.380 & 0.200 \\
\hline Gender & 0.357 & 0.459 & 0.099 & -0.766 & 0.318 & -0.351 & -0.137 & 0.749 & -0.043 \\
\hline Education & 0.034 & 0.024 & 0.011 & -0.173 & 0.165 & -0.063 & -0.038 & 0.491 & -0.008 \\
\hline Farming experience & 0.018 & 0.751 & 0.005 & 0.014 & 0.415 & 0.004 & -0.008 & 0.537 & -0.003 \\
\hline Constant & 14.529 & 0.001 & & -0.616 & 0.901 & & -7.246 & 0.053 & \\
\hline
\end{tabular}

Likelihood ratio test of rho2 $1=$ rho31 $=$ rho32 $=0$ chi2 $(3)=3.28304$ Prob $>$ chi $2=0.0000$

Wald chi2 $(63)=113.41$ Prob $>$ chi2 $=0.0001$ Log likelihood $=-128.64298$. 
are also likely to adopt another. These diagnostic tests further support the use of multivariate probit regression and indicate that use of simple probit will result in inconsistent estimates.

\section{Effect of variety attributes on adoption of Gadam variety} The results presented in Table 4 show that farmers adopted the Gadam variety because of its desirable attributes in terms of yields, pest resistance, brewing qualities, ease of cooking, and ability to yield a price premium. Price was positive and significant at the $1 \%$ level, whereas ease of cooking, yield, and brewing quality were positively significant at the $5 \%$ level. The finding on price is consistent with the hypothesis that market incentives affect farmers' adoption decisions. As expected, a price premium is an incentive for farmers to supply more for the market hence high adoption rates. Similar results were reported by [16] who showed that market price influenced pigeon pea variety adoption in the Taita District of Kenya. Pest resistance trait was also positive and statistically significant at $10 \%$. The importance of pest resistance could be due to the serious economic damages pests can cause to different varieties of the same crop [19]. A study by Legese et al. [20] shows that if a given household perceives that a given improved variety has better pest resistance ability, it increases the area under the improved variety by $19 \%$. The marginal effects results showed that the variety attributes had the greatest effect on the probability of adoption. For instance, if the farmer perceives the variety's pest resistance, yield and ease of cooking to be good, the probability of adoption will increase by $0.7 \%, 0.5 \%$, and $0.4 \%$, respectively.

Among the socioeconomic factors, age, education, and household size had statistically significant coefficients. The negative coefficient of age implies that the probability of adopting Gadam variety decreases with an increase in the age of the farmer. This could be explained that, older people are less receptive to new technologies and are not willing to take risks. The results of the marginal effects imply that a $10 \%$ increase in age will lead to a $5 \%$ decrease in the probability of adoption. The coefficient for education is positive and statistically significant at the 5\% level. As expected, well educated producers have the human capital to more fully understand and utilize information than those without management expertise [21]. The results also suggest that the likelihood of adoption increases with increase in the household size. This implies that bigger households provide the required farm labor associated with the use of new technology. The coefficient of the number of extension visits was positive and statistically significant at $1 \%$. The positive effect of extension shows the role that proactive extension can still play in accelerating technological change in smallholder agriculture in Africa. The finding that extension enhances the adoption of improved agricultural technology corroborates those of Alene and Manyong [22].

\section{Effect of variety attributes on the adoption of Serena variety}

Serena is the most popular improved variety in the study area. The multivariate probit results show that some varietal attributes influencing adoption of Gadam variety also affected the adoption of Serena variety. These include yield potential, pest resistance, and ease of cooking. Similar results were reported in Uganda by Shiferaw et al. [23]. The statistical significance of ease of cooking could be attributed to the scarcity of firewood in some areas of the region and the high incidence of poverty in the study area.

The results of the marginal effects further suggest that if a farmer perceives the yield attribute as being good, the likelihood of adopting Serena variety increases by $0.34 \%$, whereas a similar perception on ease of cooking and pest resistance traits is expected to increase the probability of adoption by $0.33 \%$ and $0.56 \%$, respectively. These results suggest that the popularity and widespread adoption of Serena variety was driven by its desirable attributes in terms of production and consumption.

Among the socioeconomic factors, only off-farm income affected the likelihood of adopting Serena variety. A 10\% increase in off-farm income increases the probability of adopting Serena by $2 \%$. The results agrees with the previous findings in this study on the role of income obtained from such activities in purchasing farm inputs such as improved seeds, fertilizer, and pesticides. The number of extension visits was also significant at $10 \%$. This further reaffirms the importance of extension visits in exposing farmers to improved technology.

\section{Effect of variety attributes on the adoption of Kimbeere variety}

The coefficients of taste and pest resistance traits were positive and statistically significant at $10 \%$ while that for drought tolerance was significant at $5 \%$. Drought tolerance is probably important because there are frequent droughts in the study region. It was apparent from the study that the local Kimbeere variety had better drought tolerance attributes than the improved varieties. The significance of the taste attributes shows how consumption attributes play a major role in influencing the adoption decision of the farmers. Similar results were reported by [16]. The coefficient for yield and ease of cooking are both negative and statistically significant at $5 \%$ and $10 \%$, respectively. These results imply that the farmers preferred the local Kimbeere variety partly because of its desirable attributes in terms of production and consumption.

Among the socioeconomic variables, household size was statistically significant at $1 \%$. The results also indicate that a $1 \%$ increase in household size will increase the probability of adoption by $0.4 \%$. Group membership was also found to affect the adoption of Kimbeere variety. This variable was negative and statistically significant at the 5\% 
level. The results of the marginal effects show that a $10 \%$ increase in the number of farmers belonging to a group decreases the likelihood of adoption by $2 \%$. This finding implies that group membership reduces the likelihood of adoption of local varieties. Indeed, groups enhance sharing of information among farmers. As such, farmers may share information on new seed varieties and even pool their meager resources in order to purchase farm inputs such as fertilizer which would have otherwise been expensive on an individual basis. Similar results were reported by [24]. Similarly, the number of extension visits had a negative and statistically significant coefficient. The inverse relationship between the number of extension visits and adoption of Kimbeere variety could probably be due to too much focus on improved varieties and neglect of traditional varieties.

\section{Conclusion and recommendation}

The study shows that both local and improved sorghum varieties are grown in the study area. However, among the five improved varieties disseminated in the study area, only two varieties, namely Gadam and Serena, had been widely adopted. The local varieties had the preferred taste, ability to tolerate drought for longer periods of time and better brewing qualities than the improved varieties while on the other hand, the improved varieties had desirable maturity periods, good grain yield capacity, yielded premium market prices, and took the shortest time to cook. The results of the multivariate probit analysis showed that variety specific attributes (yield, pest resistance, ease of cooking, ability to yield a price premium, taste, and brewing quality), farmer specific factors (age and education), institutional factors (extension visits and group membership), and endowment with physical and financial assets are the key drivers of adoption of improved sorghum varieties. However the magnitude of effect varies across different varieties. Contrary to our expectations, it was also found that early maturity trait did not appear to influence the adoption of improved seed varieties.

The policy implication from this study is that in their effort to develop new improved sorghum varieties, breeders should also focus on non-yield attributes for instance taste, brewing qualities, and ease of cooking as they matter a great deal in explaining the high adoption of improved sorghum varieties. Second, it is important that producers, processors, and consumers of sorghum be involved in seed evaluation processes. This will ensure that both production and consumption attributes of improved seeds are well evaluated and accepted by the targeted end users before disseminating the varieties to the market. Finally, policies that enhance adoption of improved seeds should also be enacted. These include investment in education and providing extension services to the farmers.

\section{Competing interests}

The authors declare that they have no competing interests.

\section{Authors' contributions}

AG conceived the study, participated in its design, data collection and drafting the manuscript. RM participated in reviewing the draft from time to time and approved the final manuscript JJ participated in designing the study and proposing the appropriate methodology. MK coordinated data collection and analysis and in reviewing the manuscript. All authors read and approved the final manuscript.

\section{Author details}

${ }^{1}$ International Livestock Research Institute, Nairobi, Kenya. ${ }^{2}$ University of Nairobi, Nairobi, Kenya. ${ }^{3}$ Tegemeo Institute of Agricultural Policy and Development, Nairobi, Kenya.

Received: 1 October 2013 Accepted: 31 March 2014

Published: 9 May 2014

\section{References}

1. Ecarsam: Sorghum and millet research for development in Eastern and Central Africa 2005-2010. 2005, Regional Priorities.

2. Fao and icrisat: The World Sorghum and Millet Economies: Facts, Trends and Outlook. 1996, http://oar.icrisat.org/1024/.

3. FAOSTAT: FAO Statistical Database. Rome: Food and Agriculture Organization of the United Nations; 2007.

4. Ecarsam: Eastern and Central Africa Regional Sorghum and Millet Network. 2007, http://www.asareca.org/ecarsam/about/background.htm.

5. KFSSG: Kenya Food Security Steering Group Long rains Assessment Report. 2008.

6. Okuthe IK, Ngesa FU, Ochola WW: Socio-economic determinants of adoption of improved sorghum varieties and technologies among smallholder farmers in Western Kenya. Nairobi: Ministry of Agriculture and Egerton University; 2000.

7. Monyo ES, Mgonja MA, Ngereza JA, Rohrbach DD: Adoption of improved sorghum and pearl millet varieties in Tanzania. Int Sorghum Millets Newsletter 2002, 43:12-14.

8. Nega W: Farm-level adoption of new sorghum technologies in Tigray Region Ethiopia. Dissertation. West Lafayette, IN: Purdue University; 2003.

9. Mafuru JM, Norman DW, Langemeier MM: Ex-ante adoption analysis for improved sorghum varieties in the lake zone; Tanzania. Afr Crop SciConfProc 2007, 8:1215-1219.

10. Nkonya E, Shroeder T, Norman D: Factors affecting adoption of improved maize seed and fertilizer in Northern Tanzania. Agric Econ 1997, 48:1-12.

11. Zavale HE, Mabaya E, Christy R: Adoption of improved maize seed by smallholder farmers in Mozambique. Staff Paper SP 121065, Cornell University, Department of Applied Economics and Management; 2005.

12. Salasya B, Mwangi W, Mwabu D, Diallo A: Factors influencing adoption of stress tolerant hybrid (WH 502) in Western Kenya. Afr J Agric Res 2007, 2:544-551

13. Greene HW (Ed): Econometric Analysis. Upper Saddle River, NJ: Prentice Hal; 2003.

14. Gedikoglu H, McCann L: Impact of off-farm income on adoption of conservation practices. Portland, OR: Paper presented at the American Agricultural Economics Association annual meeting; 2007. July 29 to August 1, 2007.

15. Marenya PP, Barrett CB: Household-level determinants of adoption of improved natural resources management practices among smallholder farmers in Western Kenya. Food Policy 2007, 32:515-536.

16. Otieno ZA: The role of varietal traits in the adoption of improved dryland crop varieties: The case of pigeon pea in Kenya. Afr J Agric Res 2011, 6:176-193.

17. Cappellari L, Jenkins SP: Multivariate probit regression using simulated maximum likelihood. Stata J 2003, 3:278-294.

18. CBS: Geographic dimensions of well-being in Kenya. Who and where are the poor. A constituency level profile (Volume Two). Nairobi: The Legal Press Kenya Limited; 2005.

19. Shanower TG, Romeis J, Minja EM: Insect pests of pigeon pea and their management. Annu Rev Entomol 1999, 44:77-96.

20. Legese G, Langyntuo A, Mwangi W, Jaleta M, La Roberto R: Household Resource Endowment and Determinants of Adoption of Drought Tolerant Maize Varieties: A Double Hurdle Approach. In Paper Presented at the International Association of Agricultural Economists Conference. Beijing China: 2009. August 16-22, 2009. 
21. Mishra AK, El-Osta HS: Managing risk in agriculture through hedging and crop insurance: What does a national survey reveal? Agric Finance Rev 2002, 62:135-148.

22. Alene DA, Manyong VM: Farmer-to-farmer technology adoption and yield variation among adopters: The case of improved cowpea in northern Nigeria. Agricl Econ 2007, 35:203-211.

23. Shiferaw BA, Obare G, Muricho G, Silim S: Leveraging institutions for collective action to improve markets for smallholder producers in less-favored areas. Afr J AgricResour Econ 2009, 3:1-18.

24. Katungi EM: Social capital and technology adoption on small farms: The case of banana production in Uganda. Dissertation. Pretoria: University of Pretoria, South Africa; 2007

doi:10.1186/2048-7010-3-9

Cite this article as: Timu et al:: The role of varietal attributes on

adoption of improved seed varieties: the case of sorghum in Kenya.

Agriculture \& Food Security 2014 3:9.

\section{Submit your next manuscript to BioMed Central and take full advantage of:}

- Convenient online submission

- Thorough peer review

- No space constraints or color figure charges

- Immediate publication on acceptance

- Inclusion in PubMed, CAS, Scopus and Google Scholar

- Research which is freely available for redistribution 